\title{
Students are the major source for proliferation of corruption in higher education in Azerbaijan. ${ }^{1}$
}

\author{
Volodymyr V. Gulyk \\ Azerbaijan Diplomatic Academy \\ Baku, Azerbaijan
}

\section{Introduction}

According to research conducted in 2008 by "Psychological Center" in Azerbaijan almost $40 \%$ of students and academics and every second teacher at state universities accepts bribes ${ }^{2}$.Corruption has become the most dangerous virus of the 21 th century. It has different sources and can affect different sectors and as any other social disease it starts in schools as well as in family circle. Corruption in society (in all its areas) can become a big problem when it starts to grow in education sectors. This paper accepts the existence of corruption in higher education in Azerbaijan. Most students (as well as the whole population) tend to blame the government for the lack of the initiatives in combating corruption. However, this is the first attempt to prove the theory, that students are more responsible for corruption at universities than university atmosphere, its structure and behavior. Moreover, some research has emphasized fact the government has failed to reform the system that creates the situation in which giving-taking a bribe is possible ${ }^{3}$ because the state administration does not know how to replace existing scheme and does afraid that it will cost them big money. Despite different opinions about its level of existence, the author has verified the main cause of the denial of continuation bribery. Next step supports the fact that students' behavior of giving a

\footnotetext{
${ }^{1}$ This article was made possible by many people from different countries, who provided useful commentary on various parts of the manuscript. The author would like to extend his sincere appreciation to Molly Burke-Kirova, James Balzano, Tomas K. Gerbasio, as well as to whole contributors and interviewees, who helped to conduct the research project.

${ }^{2}$ Психологический Центр, "Коррупция в системе образования: состояние, причины и пути решения (социологический и социально-психологический анализ)", reasearchconductedin 2008 inAzerbijan. No authors were mentioned,http://psychology.az/project_corr.php (accessed December 17, 2011).

${ }^{3}$ Silova I., Budiene V. and Bray M., "Education in a Hidden Marketplace: Monitoring of Private Tutoring", Open Society Institute 2006, p. 124-125.
} 
bribe is the major reason for proliferation of corruption in higher education. The established hypothesis is proved in the third part of the paper. Data, gathered from student's interviews is analyzed.

There has been little research conducted on corruption in the education sector in Azerbaijan as it is not a topic the government would be proud of. Hence, because it has been only modestly examined there are very few sources on it. Another important fact is that most publications emphasize, in contrast to my point of view, that the weak will of the government, in particular in higher education sector in Azerbaijan causes corruption in society. Partially this is true, but according to Central Eurasia Project of the Open Society Institute, this is because the administration officially holds that there is "a lack of serious problems" in the country. Taking this into account, the author of this essay uses mostly foreign analysis and sites researches which were published abroad.IvetaSilova, Mark S. Johnson and Stephen P. Heyneman in their article ${ }^{5}$ present the process of creation of the present education system in Central Asian countries. Their paper is divided into 2 parts: creation of education before and after 1991. The authors mainly try to concentrate on the description of the "health status" of learning process and problems related to it. Also the authors warn that if the educational scheme is not be changed, "young people [will] continue to emigrate or seek escape in drug abuse, illegal activities, or social alternatives in the form of nationalism, political radicalism, or religious extremism" government wanted to hold Islam in the country, but did not know where exactly put it and the best place for religious thoughts and values was in education system. Although in that time educational was already secular and attempts to do so usually were half-hearted, but this is separate research question and should be conducted in discrete research paper.

Important information about corruption in the education sector can be found in "Ethics and Corruption in education" and "Education and Corruption". Those two

\footnotetext{
${ }^{4}$ Abbasov S., "FightingCorruptioninAzerbaijan: A MissionwithTeeth?”,Eurasianet, 23 February 2011, http://www.eurasianet.org/node/62947

${ }^{5}$ Silova I., Johnson M. S. and Heyneman S. P., "Education and the Crisis of Social Cohesion in Azerbaijan and Central Asia", Comparative Education Review, vol. 51, no. 2 (February 2007):159180 , http://www.vanderbilt.edu/peabody/heyneman/PUBLICATIONS/Ed.\%20and\%20the\%20Crisis\%20of $\% 20$ Social $\% 20$ Cohesion $\% 20$ in $\% 20$ Azerbaijan\%20and\%20Central $\% 20$ Asia.pdf ${ }^{6}$ Ibid., p. 161.

${ }^{7}$ Hallack J., Poisson M., „Ethics and Corruption in education”, Policy Forum, no. 15, Paris 2002, http://www.unesco.org/iiep/PDF/Forum15.pdf
} 
sources were also written by foreigners; provide general data on the sources and consequences of bribing. In "Corruption in Higher Education: Some Findings from the States of the Former Soviet Union" the reader can find more detailed facts about corruption in the Azerbaijani Education system such as: "bribes paid are in many ways more in the nature of fees" and for passing a single examination the student has to pay from "US\$10 up to US\$100" 10 . The report from national seminar in Baku (which was held in February 2006) is also quite valuable, because it brings up information about anti-corruption issues in Azerbaijan ${ }^{11}$. However, Isaxanli, in his article «Strengths and Weaknesses of Private Universities in a Transition Economy: A View from Azerbaijan" presents an opposite view ${ }^{12}$. He concludes that the educational system itself is a source of corruption in the government, because the whole authority system is corrupted, including government, ministry, ruling departments and universities. On the other hand, Isaxanli emphasizes that lack of universities autonomy lead to bribery spread, as they have to be an integral part of the system and cannot fight this disease on their own. Also similar thought we can find in his "On Education System in Transition Economy: A View from Azerbaijan". The paper itself is a compilation from different conferences and provides good review on educational trends in Azerbaijan as well as describes modernization effects on education.

Authors of "Education in a Hidden Marketplace: Monitoring of Private Tutoring" present the corruption in education in Azerbaijan from different perspectives ${ }^{13}$, and also concerned other countries such as Ukraine, Poland, Slovakia, Georgia, Mongolia, Croatia, Bosnia and Herzegovina. The report shows that instead of paying a bribe people more often use private teaching as a "ticket" to universities as well as

\footnotetext{
${ }^{8}$ Stephen H. P., „Education and Corruption”, International Journal of Educational Development, vol. 24, No. 6 (November 2004): 637-648, http://www.vanderbilt.edu/peabody/heyneman/PUBLICATIONS/Education\%20\&\%20Corruption.pdf ${ }^{9}$ Temple P.,Petrov G., "Corruption in Higher Education: Some Findings from the States of the Former Soviet Union", Higher Education Management and Policy, vol. 16, no. 1, 2004, p. 89-97, http://www.oecd.org/dataoecd/22/33/37443688.pdf

${ }^{10}$ Ibid, p. 87, 92.

11“"Anti-corruption issues in education”, International Institute for Educational Planning, http://www.iiep.unesco.org/fileadmin/user upload/Research Highlights Corruption/pdf/Rapport Az erbaijan AZ.pdf

${ }^{12}$ Isakhanli H., "StrengthsandWeaknessesofPrivateUniversitiesin a TransitionEconomy: A ViewFromAzerbaijan", http://portal.edu.az/English/Pages/strengthsandweaknessesofprivateuniversities.aspx

${ }^{13}$ Silova I., Budiene V., Bray M., "Education in a Hidden Marketplace:

Monitoring of Private Tutoring", Open Society Institute 2006, http://www.soros.org/initiatives/esp/articles_publications/publications/hidden_20070216/hidden_200 $\underline{70216 . p d f}$
} 
an easier way to pass exams. Recent reports of Transparency International also indicate that corruption in higher education sector is growing constantly ${ }^{14}$.

\section{Specifying the problem}

In reference to results presented in "Global Corruption Barometer 2010",it can be argued that Azerbaijan is one of the countries where corruption is most prospering. Azerbaijan is ranked in group number 2, where 30-49.9\% respondents reported paying a bribe in the past 12 months, and $20 \%$ of these respondents paid a bribe for "services" in the education system ${ }^{15}$. Although, the situation is getting worse, based on perception of anti-corruption government policy, only $30 \%$ of respondents answered that efforts taken by the government are effective ${ }^{16}$. In addition, $52 \%$ of informants stated that level of corruption in the country has increased over the past three years ${ }^{17}$. Therefore, problem of corruption in education is becoming even more a serious threat to society.

According to professors of University of London, Paul Temple and Georgy Petrov the main reasons of existence of corruption in high schools are as result of low teacher salaries and poor prospects after retirement as well the legacy of the Soviettype higher education system, substituting for state funding and "Mentality"18. This paper, however seeks to prove that student's behavior contributes to corruption expanding process. Using the term of "student's behavior", the author means process of giving the bribe by students to the academics and other individuals connected with the university. This includes giving money in order to buy grades at universities, "buying” scholarships, dormitory places etc.

In this paper the author omit the cases where the students were forced to pay a bribe by their own parents, because they were educated in such a system where corruption was normal. This is very important psychological phenomenon, but it requires entire separate research and study paper.

\footnotetext{
${ }^{14}$ The 2010 CorruptionPerceptionsIndex, http://www.transparency.org/content/download/55725/890310; The 2009CorruptionPerceptionsIndex, http://www.transparency.org/content/download/53383/851857/CPI+2009 Sources bycountry.pdf

${ }^{15}$ Riano J., Heinrich F., Hodess R., Global Corruption Barometer 2010, Transparency International, (December 2010): 41-44. At the moment of writing the 2011 edition was not published yet and this is the reason the author is relying on 2010 and 2009 data.

${ }^{16} \mathrm{Ibid}, \mathrm{p} .25$.

${ }^{17} \mathrm{Ibid}, \mathrm{p} .43$.

${ }^{18}$ Temple P., Petrov G., "CorruptioninHigherEducation:

SomeFindingsfromtheStatesoftheFormerSovietUnion”, HigherEducationManagementandPolicy, vol. 16, no. 1, 2004, p. 90-91.
} 
To restate, the majority of authors like people of Azerbaijan tried to emphasize that system is responsible for corruption proliferation in the education system. The components of the "system" include its structure, methods of teaching, customs and traditions, influence of other societies and teachers poverty. This paper does not reject that fact, or neglect the role of mentioned factors, but takes an attempt to argue that the main responsibility lays in students' actions. Low interest in knowledge (36\%) and lack of punishment system in education $(17 \%)^{19}$ are one of the main reasons of corruption existence according to the results from 2008.

It is arguable that bribery in the educational system is structured hierarchically from up to down (from government to ministry of education and then to the universities), but the actions of buying a mark or admission, is made by students themselves and the excuses of 'outside influence' are weak, because they do not justify today's situation. Specifically some researchers claim that corruption as phenomenon was brought from abroad to Azerbaijan. Firstly it was done by soviets $^{20}$, then by western oil companies, but "this is not a matter of winners and losers...culture of corruption affects everybody" ${ }^{\prime 21}$. It is difficult to ignore these statements, however, it only explains why corruption exists, and how it arose in the education system. This historical background is not relevant in explaining corruption because the majority of students in universities were born after the Soviet Union's dissolution.

On the other hand, there are such cases when the teachers demand money for particular marks, but these are extreme situations ${ }^{22}$. Generally, corruption in Azerbaijan education system involves behavior of students and academics as accomplices. This paper proves the existence of lack of respect for educational 'value', which causes the process of feeding the corruption by students. In addition, the excuses provided by academics and students are quite opposite. $31 \%$ of students blame teachers for 'demanding' the bribe and $37 \%$ of academics justify themselves by saying that they are helping the students ${ }^{23}$.A similar answer we can hear from the parents of students, who know how the "system works", but this is separate topic for another research and worth pursuing, since they obviously include this idea in their kids.

\footnotetext{
${ }^{19}$ «Психологический Центр» conducted research in 2008.

${ }^{20}$ Temple P.,Petrov G., p. 91; IvetaSilova, Mark S. Johnson and Stephen P. Heyneman, p. 164.

${ }^{21}$ Heradstveit D., Bonham M. G., ,The Psychology of Corruption in Azerbaijan and Iran” in Oil in the Gulf, Ashgate, Chippenham 2004, 72-99.

${ }^{22}$ Ibidem, p. 93-95.

${ }^{23} 13 \%$ - students do not want to study; $12 \%$ helping students with academic paper writing; $9 \%$ 'stupid student'; 3\% - “rich student”. «Психологический Центр» conducted research in 2008.
} 


\section{Methods and Data Collection}

Two different methods of data collection were used; interviews and questionnaires (see appendix A). At the initial stage, I studied the level of student's interest in education they have chosen. By saying "education" the researcher means learning process, usefulness of the information gathered at university, quality of studying (teacher's preparation, university equipment etc.) in contrast to obtaining the diploma only (as a document/degree). Research proves that while the student's interest in knowledge has been decreasing, the possibility of paying bribe for exams, absence excuse, 'better' marks, and scholarship has risen.

At the next step, the perception of corruption among students was evaluated. For instance, if the practice of paying money for passing an exam is seen as a violation of law the informant would not pay bribe (or at least there is less possibility that he would). Moreover, if the informant perceives corruption as a normal custom, or "unavoidable" practice, because of the erosion of the whole system, than financial transaction would be more likely to occur.

\section{Limitations}

One can argue that such kind of no probability sampling (students of Azerbaijan Diplomatic Academy only) would not be representative, because of the small amount of respondents. The author of this paper is aware of that fact but the main reason for it is limitation of the research. More funds, human and time resources are needed to provide more probable and representative study. This academic paper should be treated as an attempt to provide the main hypothesis and emphasize the problem in educational environment in Azerbaijan. At the same time, the author of this paper should underline the fact that studied problem does not apply to Azerbaijan Diplomatic Academy,Khazar University and Qafqaz University, since they are newly established schools, which do not share soviet principles. Moreover, the wide autonomy ${ }^{24}$ of those universities ${ }^{25}$ gives an opportunity to create an environment with US and EU standards and acceptance of students who are interested in gathering of knowledge only, thus allowing avoidance of corruption practice, because 'bribe-givers' are not interested in it, nether 'bribe-takers'. Once again, the author is not trying to prove that students are the only source of the

\footnotetext{
${ }^{24}$ Here the author means autonomy from the structured educational system, since Khazar University, Qafqaz University are private institutions and Azerbaijan Diplomatic Academy is functioning under Ministry of Foreign Affairs patronage.

${ }^{25}$ Report of «Психологический Центр» says that Khazar University is not corrupted in comparing to other Azerbaijan universities. http://psychology.az/corruptiongraf_st.php
} 
corruption, but it is major reason why corruption still exists and didn't disappear together with USSR. Of course, the presence of 'bribe-takers', university atmosphere and structure precondition matters a lot, but this is not a reason why this disease still expanding.

\section{Data analysis. Students apathy and low interest in knowledge creates the} situation in which corruption occurs.

Survey results proved the assumption that today in Azerbaijan corruption is common in higher education. $21.4 \%$ of the respondents perceive corruption as 'Normal practice', while $24.2 \%$ stating that it is NOT a crime. Thus, we can deduce that every fifth student in Azerbaijan thinks that it is 'normal', every fourth does not perceive it as a crime act and every third pays a bribe. The graph below illustrates the numbers.

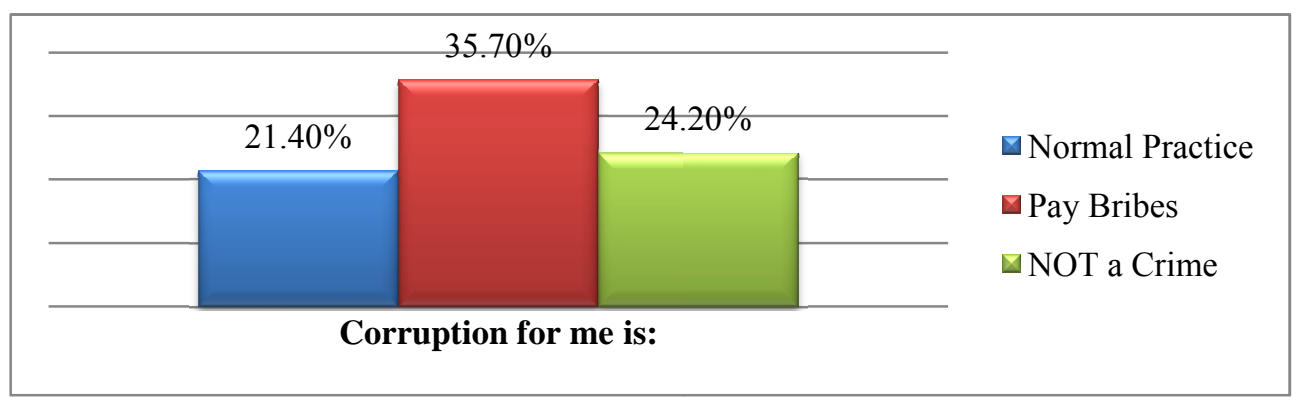

Graph 1.Attitude of Azerbaijani students towards corruption practice ${ }^{26}$.

It is unbelievable that almost half of the respondents perceive paying a bribe as common practice in education in Azerbaijan. Some argue that it is because the whole society at every level is corrupted. Government and the 'system' create the environment where people think that bribe is something 'normal'.

Nevertheless, it is important to examine in which situations the action of paying the bribe occurs. In the conducted survey, there are two extreme positions. Bribery is least common during entering the university process, obtaining scholarships, dormitory places, and concerning issues with library and documents $(87.1 \%$ and 93.5\% respectively, see graph below). According to respondents, most often a bribe is paid for passing the exam/test and during the graduation process, $-67.7 \%$ and $71 \%$ respectively.

\footnotetext{
${ }^{26}$ The survey data is from questionnaire and interviews carried out in Baku in October-November 2011. All further data if not cited from other source comes from my research. For more details, see statistics appendix B.
} 


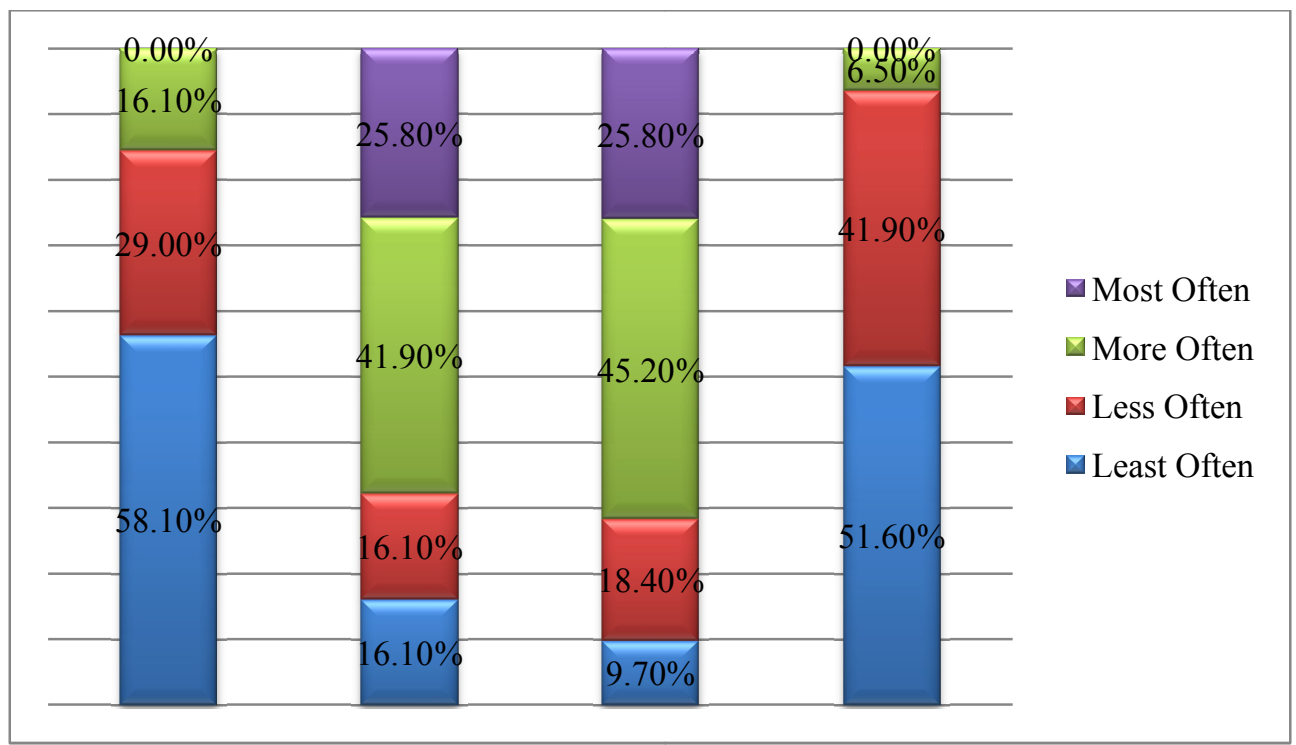

Graph 2. What are situations when corruption occurs?

Graph 2 shows that main 'engine' of corruption lies in the middle of the studying process and during graduation. This happens mainly because of student's apathy, which may be rising in 21 st century. A fast modernization route, rising amount of information, new technologies and new types of entertainment ${ }^{27}$ make students less interested in knowledge. Universality in education, in which every student necessitates a degree, in particular in Azerbaijan, leads to 'inflation of diplomas'. Other research calls it 'credential inflation" 28 , but it indicates only devaluation in sense of knowledge. It means that the skills of diploma's holder are not sufficient for an employer anymore. Further to this definition should be added the problem with the rising number of diplomas. In $21^{\text {st }}$ century more and more individuals come to the University for Degree, because employers require it. This is worldwide observable fact ${ }^{29}$. The problem of credibility and recognition of degrees puts Azerbaijan even in worse situation, which causes 'inflation of diplomas' and that is why it loses its value. For future employees, the distinction between obtaining diploma and obtaining knowledge has become less. Next graph explains it in more detail.

\footnotetext{
${ }^{27}$ As well we can question the real value of the degrees, because of prospering of new technologies. For ex. recent 'neutrino' experiment proved that all physics degrees, based on Einstein science are not necessarily actual.

${ }^{28}$ Collins R., "Comparative and Historical Patterns of Education" in Handbook of the Sociology of Education, ed. Maureen T. Hallinan(New York: Kluwer Academic/Plenum Publishers, 2000), p. 213239.

${ }^{29}$ Ibidem.
} 


\section{What is the most important for you at university?}

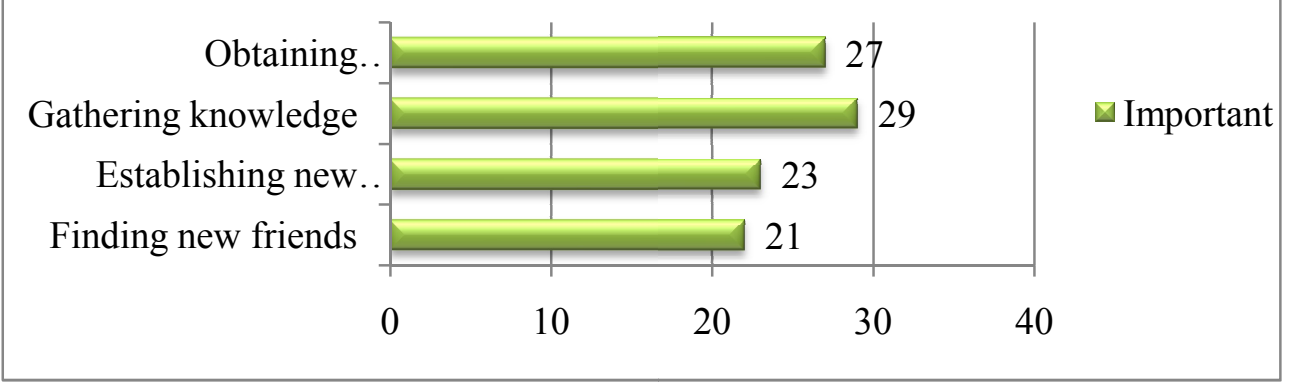

Graph 3.Importance in education for students.

By interpretation of third the graph it is clear that for Azerbaijani students the purposes of entering university are almost equally divided between certain groups. The most important, accordingly to this study is gathering of knowledge. Of course, it is very important and the author of the questionnaire does not want to prove opposite. I used the group of 'importance of gathering of knowledge' as a control group to which all other 'purposes' were compared. However, unexpected results showed that obtaining the diploma or degree (in sense of proving the participation in education process) reached were also slightly lower than gathering of knowledge, but still high in comparing to it. A little bit less but still visible purposes are making of new 'connections' and finding new friends. We can assume that students gave the answers from the perspective of job placement after the graduation of the university. This fact tells us that Azerbaijani students are interested in studying and obtaining of new skills by only $30 \%$ as opposed to $42 \%$ of finding new friends and connections. This is the major reason which explains why bribery still exists in education sector of Azerbaijan.

One can argue that for the job seeking process those results are perfect - balanced between diploma, knowledge, friends and possible employers and it does not depends on the region. In comparing to North America or Europe, potential employees as well need to have connections and friends in order to find a job. Nevertheless, the major advantage of job seekers is his or her skills and knowledge. In Azerbaijan students need new friends and connections at the same level as skillfulness. That's why they are still willing to pay a bribe instead learning and passing the exam.

To prove this theory, survey informants were asked directly: "What makes you better candidate for placement in employment?". Among three answers the main advantage is 'knowledge and skills', than 'friends and connections' and 'diploma 
from prestige university' as the last one. The pecking order is correct, but distance between those answers still very low $-8 \%$.

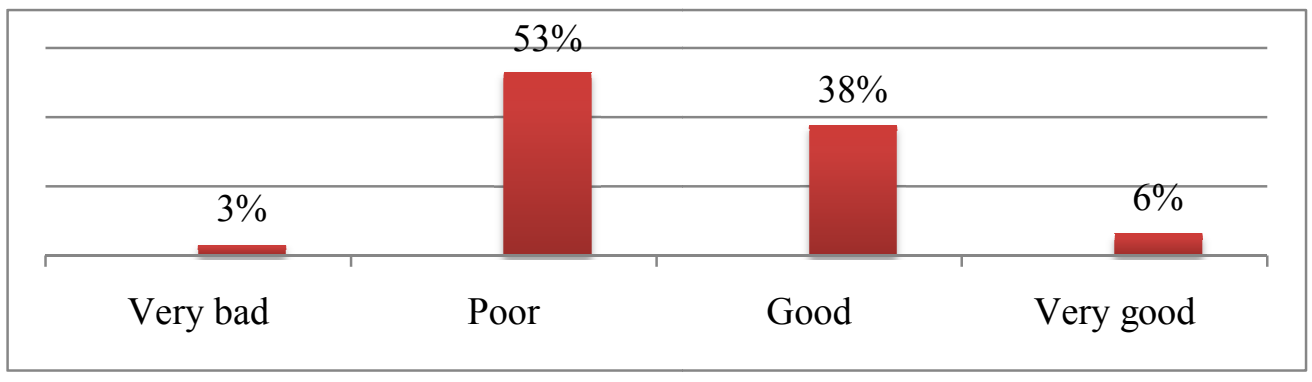

Graph 4. What is the quality of education in Azerbaijan?

If we go deeper and investigate these statistics we would find that Azerbaijani society works through connections and acquaintances. This is a clearly soviet scheme, where some goods were prohibited to sell or just unavailable on the market and an individual needed to know somebody from that particular sector in order to obtain the good. This dilapidated education sector and made it skip-able and indirectly this led us to question the quality of education.

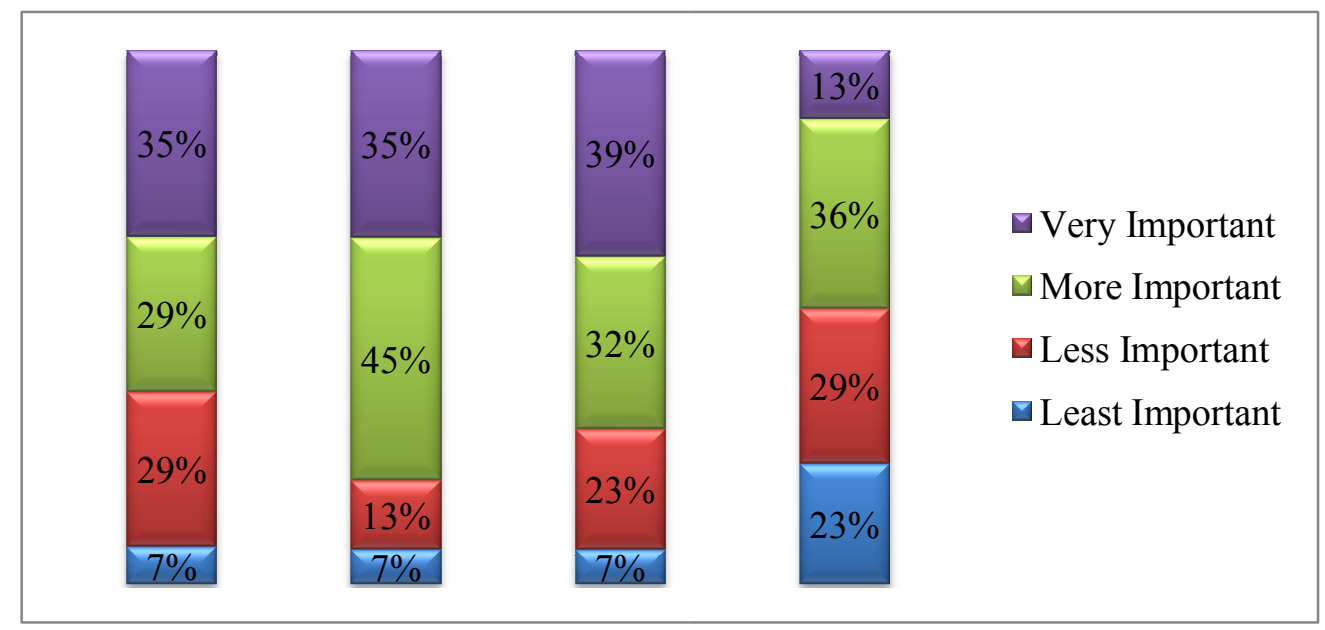

Graph 5. What are the main problems in Azerbaijani education?

Verification of the current level of instruction in Azerbaijan showed that it is more poor than good. This can explain partly why students are not interested in studying and would rather pay a bribe than study. For checking this variable informants were asked to evaluate the main problems which makes Azerbaijani education 
poor. Graph 5 presents the results. Here $80 \%$ percent of respondents stated that low quality and learning of inaccurate things is the major problem in higher education in the country. Secondly, respondents agreed (71\%) that corruption in education is one of the major diseases which the government should fight. Finally, $64 \%$ of surveyed students regarded 'poor opportunities after graduation' as an important problem in education. It seems interesting that answers from the last group - 'Lack of equipment, books' - provided puzzled situation. This graph demonstrates that students are not certain about importance of this problem in the educational sector. Explanation is not direct.

A contrast the situation introduced in Graph 5 takes us to the topic of solving the problems in education sector in Azerbaijan. We can assume that the first major problems (low quality, corruption and bad opportunities) are widespread in and common to the whole country. This makes it a complex and arduous challenge, which cannot be solved in short run. Regarding the equipment and books issue, in particular - lack of those at universities, we can agree with the claim that the resolving of it will pass easily. Buying new equipment or books and replacing old Russian ones at universities would not be a problem, especially for Azerbaijan ${ }^{30}$. Thus, because government can solve this problem, students were not sure about importance of that problem in comparing to others surveyed issues.

In the final analysis, students as bribe-givers continue to use this practice because of a wrong perception of corruption. According to the result of research, $42 \%$ of students think giving money for marks as 'salary' for teachers. This can be justified by using the argument that teacher's wages in Azerbaijan are extremely low. This problem was already indicated and to take one example - the average academic's salary varies between $200 \$$ and $300 \$ 31$. This puts teachers in a situation where they are under duress to demand a bribe, and provides justification for both students and academics. For teachers it is low salaries and for students it is blackmailing by tutors. According to this research, four students out of ten will pay bribe, because they do understand or perceive it as 'money which must be paid to teacher'. Similarly it can be seen in 2008, when "Психологический Центр" (psychological research institution) investigated main the reasons of corruption in higher education. According to its results $63.9 \%$ of respondents indicated low salaries as a main reason of corruption. ${ }^{32}$

\footnotetext{
${ }^{30}$ One can argue that there is a problem in writing of new core books in Azeri for universities, but I think that if there would be an initiative it is possible to achieve. There are English and Russian books which can be easily translated into Azeri (with the government support).

${ }^{31}$ Rashidgizi R., "Everybodygets a piece", Chalkboard, 25 November 2009, http://chalkboard.tol.org/azerbaijan2

${ }^{32}$ Report.http://psychology.az/corruptiongraf_st.php
} 


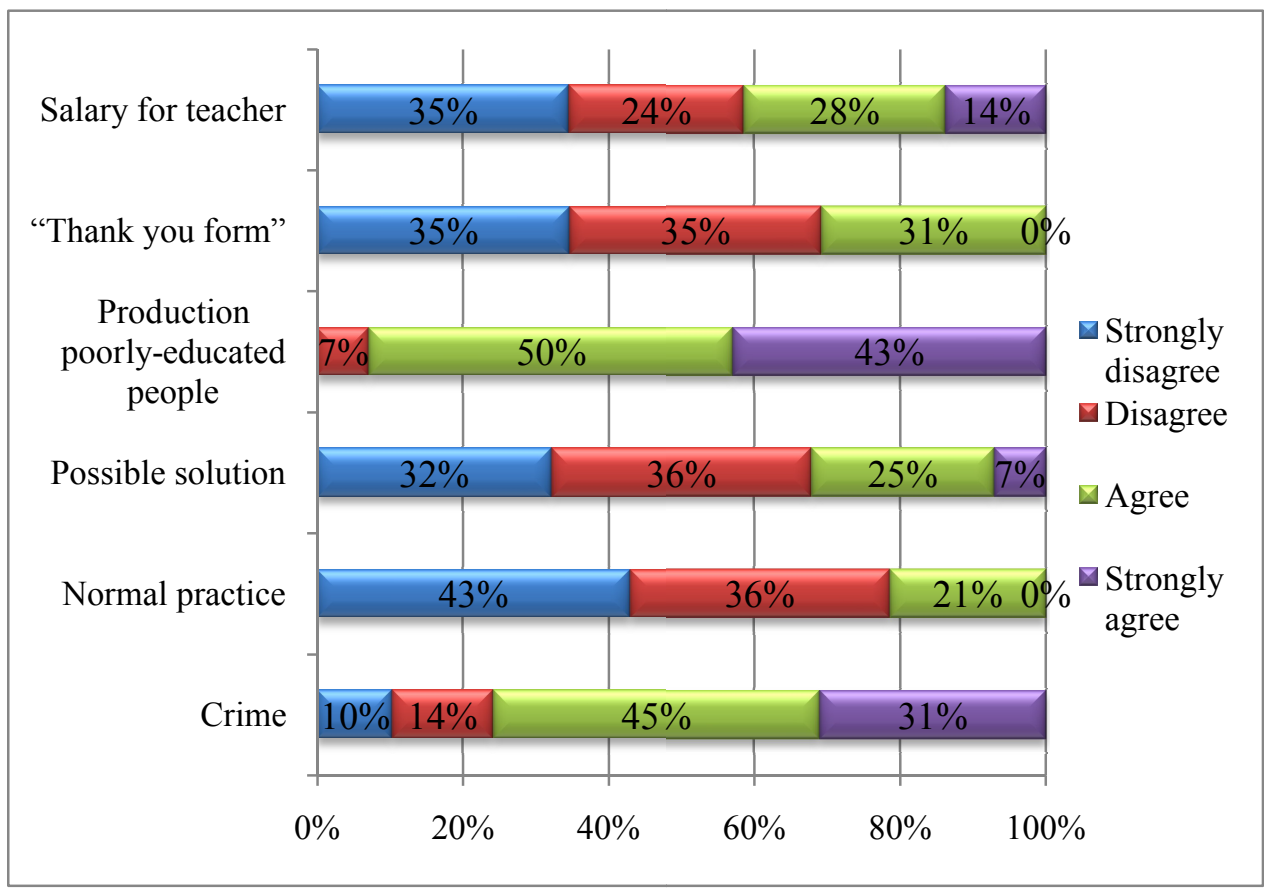

Graph 6. What is bribery for you ? Perception of corruption in education among students in Azerbaijan.

At the same time, $31 \%$ of respondents described bribery as a "thank you" form. In other words, there is another justification, in this case created by students, which allows them to pay money in order to "thank" their teacher. Moreover, when it comes to passing the exams, among respondents, every third student thinks that it is 'possible solution' to pass an exam and every fifth perceive bribery as a 'normal practice' (Graph 6). Remarkably, correlation analysis proved that among those students who uses "possible solution" $55 \%$ or more than every second one would excuse it by naming that it is "normal practice".

Nonetheless, the same question of perception was answered conversely and $76 \%$ of the surveyed students agreed that corruption practice in education in Azerbaijan is a crime. Moreover, 93\% informants strongly emphasized fact that bribery causes 'production of poorly-educated people'. In this very point we reached the essence of the today's research - majority of students do understand that giving money for marks is a crime and should be punished. They do appreciate the fact that by paying bribe they deficient themselves because of lack in human capital skills after graduation. However, at the university undergraduates still would use those excuses: "possible solution", "thank you form", "salary for teacher" and "normal practice". There are several reasons for this. 
Firstly, Silova and others argue that it is mainly because of structural conditions, which creates situation in which corruption acts can easily be accomplished ${ }^{33}$. Moreover, the system of punishment is not developed, which causes proliferation of corruption after the educational on others sectors. This meanwhile starts the process of total demoralization of society and value of education, which takes us back to corruption, because only diploma as a document, finding new friend and connections are important at a university. This will lead to erosion of the respect for the law as one of the main sources of corruption in the entire country, but that is separate topic.

Although, in graph 7 reasons of corruption are presented in education in Azerbaijan, most informants agreed that "laziness of students" is a serious cause of bribery. In comparing with others reasons, that one is the most popular and it reached $90 \%$ agreement.

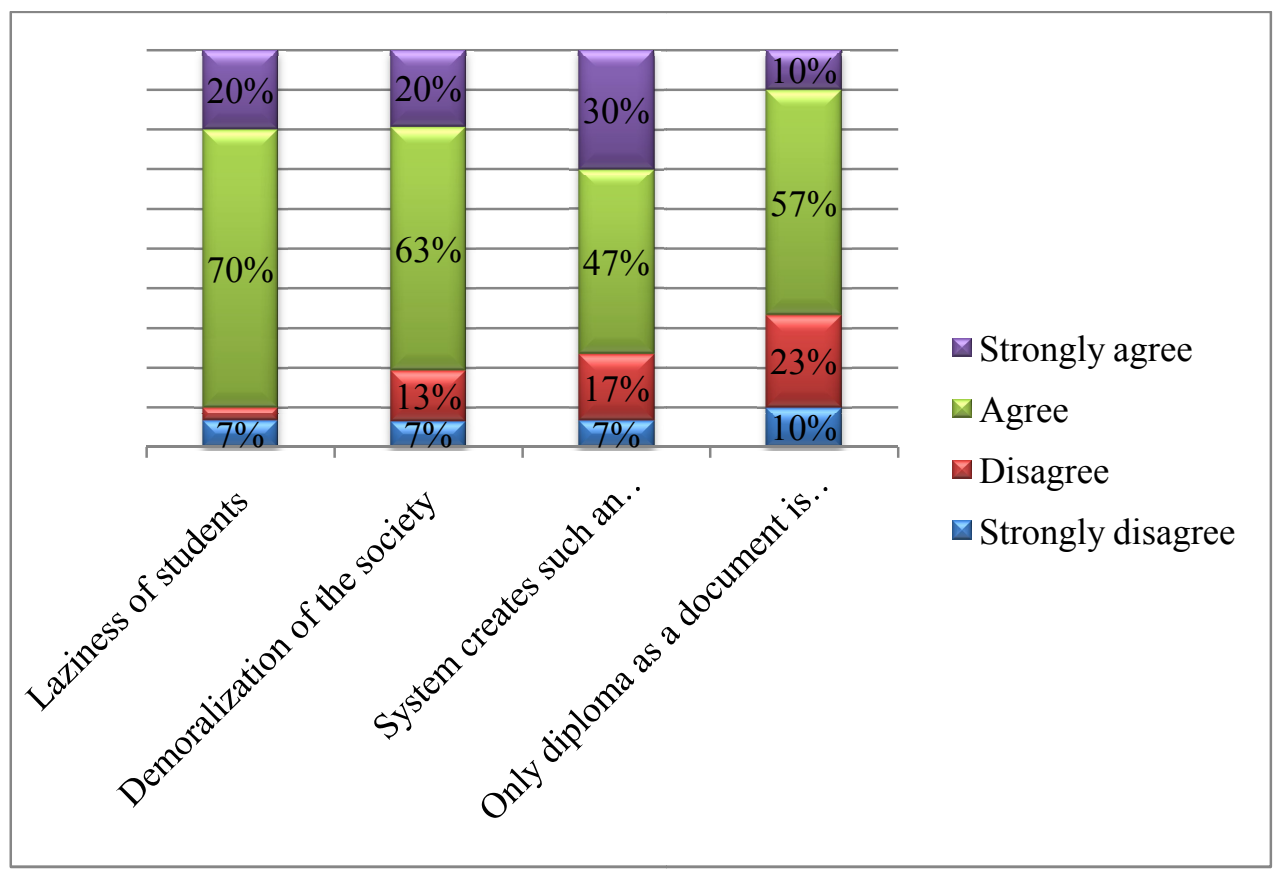

Graph 7. Why corruption in education still exists?

\section{Summary}

Today's paper shows evidence that corruption in Azerbaijani universities is significant problem. Almost $36 \%$ of students use weakness of the education system

\footnotetext{
${ }^{33}$ Silova I., Johnson M. and Heyneman S., "Education and the Crisis of Social Cohesion in Azerbaijan and Central Asia", Comparative Education Review, vol. 51, no. 2 (February 2007):164.
} 
and pay bribes. Mostly these transactions occur while passing exams and during the graduation procedure. In my opinion, this happening because of devaluation of knowledge process. Research proved, that students are losing their interest in gathering skills from a university and trying to establish new connections and friendships (not to mention marriage plans). This happens because of weak student's perception. They do believe that Azerbaijani education is poor and problem of quality of learning as well as corruption itself play an important role in "inflation process".

However, there is confusion in perception of corruption between students. Majority of informants agreed that it is crime and destroys human potential, but on the other hand, the significant minority still think that corruption acts is normal practice. Thus brings me to far-reaching conclusion that for considerable amount Azerbaijanis crime is normal practice. It shows that these who don't do it are missing out, so environment is more infected than morals.

Nevertheless, students do agree with statement that bribery in education system of Azerbaijan still exists because of laziness of students. Almost $30 \%$ of "bribegivers" paid money for exam because they did not study well $1^{34}$. On the contrary, there are still extreme situations where students are under the duress to pay, and in $48 \%$ of the cases they would.

I am not trying to say that the students are the only reason or main reason of corruption in education, but they are more responsible for its proliferation now than the centralized and corrupted educational structure. The 'bribe-takers' or even 'bribe-demanders' are responsible for establishing such a system where giving a bribe became 'normal' transaction in university's life. Although it used to be in past, and at the present moment the students are maintaining this 'sick' system in order to use the benefits it offers, for the reason that they need them. So far, they are the main reason of proliferation of corruption and they are more responsible for its existence at the present moment.

\section{Policy recommendation.}

Despites prevention of economic growth and development, the demoralization of Azerbaijani people and the destruction of social cohesion, which corruption causes, decision makers should consider the devaluation of education effect as well. It can create much bigger problems than an entire generation with lack of human capital skills. In a desperate situation, abadly educated mass will not be able to find efficient job for feeding their families and at the same time "see that they are not

\footnotetext{
${ }^{34} 22 \%$ - because teacher demanded money; $21 \%$ - because all the system is corrupted.
} 
getting their rightful share of the oil wealth" would come on the streets and will demand vengeance against the rulers ${ }^{35}$. Such a situation happened in the Middle East and North Africa with the Arab Spring in 2011.

To prevent an uprising (like in Libya's and other cases)the government as well as NGO's should emphasize the problem of devaluation in education, especially its negative implementations. Society should know that if it is paying bribes at universities it would proliferate into other sector as well. By the end of the day entire society will be blocked if it runs out of the oil money. In case of Azerbaijan there is possibility of oil depletion (next 15-25 years).

Besides advertising consequences of the bribery, autonomy to universities should be granted. In such situation educational competitive market would be created. This will allow universities to fight for new students and involuntarily diminish corruption.

Equally important is to establish exchange programs where students can spend some time studying abroad, in countries where corruption was reduced. These practices will show how much education cost and how valuable it is. Similarly, academic staff should be sent abroad for exchange experience as well as teachers from other countries should teach in Azerbaijan.

The above-mentioned strategies are long-term initiatives to curb corruption and if decision makers want to solve the problem of corruption as soon as possible, radical solutions should be applied. Specifically, redevelop a system of punishment for corruption actions in education sphere; create transparent and rigorous system of penalties. Academia, which can lose high position and reputation would rather avoid taking risk of accepting a bribe. In the meantime increase of salaries also will reduce the level of corruption in education. As Isaxanli already mentioned, the privatization in the education sector will help and boost the process of decorruption $^{36}$.

\footnotetext{
${ }^{35}$ Heradstveit D., Bonham M. G., „The Psychology of Corruption in Azerbaijan and Iran” in Oil in the Gulf, Ashgate, Chippenham 2004, p. 72.

${ }^{36}$ Isaxanli H., On Education System In Transition Economy: A View from Azerbaijan, (Baku: Khazar University Press 2006), p. 41, http://dspace.khazar.org/jspui/bitstream/123456789/1001/1/on\%20education\%20system_Isaxanli.pdf( accessed December 17, 2011).
} 
Appendix A. Questionnaire.

\begin{tabular}{|c|c|c|c|c|}
\hline $\begin{array}{l}\text { 1. Situations in which corruption } \\
\text { occurs most often (in your } \\
\text { previous university): }\end{array}$ & $\begin{array}{l}\text { Least } \\
\text { often }\end{array}$ & Less often & $\begin{array}{l}\text { More } \\
\text { often }\end{array}$ & \multirow[t]{2}{*}{$\begin{array}{l}\text { Most } \\
\text { often }\end{array}$} \\
\hline $\begin{array}{l}\text { a. While entering university } \\
\text { process }\end{array}$ & & & & \\
\hline b. For passing exams/test & & & & \\
\hline $\begin{array}{l}\text { c. For graduation process (final } \\
\text { exam, MA paper etc) }\end{array}$ & & & & \\
\hline $\begin{array}{l}\text { d. Other: to obtain scholarship, } \\
\text { dormitory, documents, } \\
\text { library. }\end{array}$ & & & & \\
\hline $\begin{array}{l}\text { 2. What is the quality of studying. } \\
\text { Underline } 1 \text { option }\end{array}$ & Very bad & Poor & Good & $\begin{array}{l}\text { Very } \\
\text { good }\end{array}$ \\
\hline $\begin{array}{l}\text { 3. At the university important for } \\
\text { you is (evaluate each option): }\end{array}$ & $\begin{array}{l}\text { Least } \\
\text { Important }\end{array}$ & $\begin{array}{c}\text { Less } \\
\text { Important }\end{array}$ & $\begin{array}{c}\text { More } \\
\text { Important }\end{array}$ & $\begin{array}{c}\text { Very } \\
\text { Important }\end{array}$ \\
\hline a. Finding new friends & & & & \\
\hline b. Establishing new connections & & & & \\
\hline c. Gathering knowledge & & & & \\
\hline d. Obtaining diploma/degree & & & & \\
\hline $\begin{array}{l}\text { 4. What makes you better candidate } \\
\text { for placement }\end{array}$ & $\begin{array}{l}\text { Don't } \\
\text { need }\end{array}$ & Maybe & $\begin{array}{l}\text { Better to } \\
\text { have }\end{array}$ & Must have \\
\hline $\begin{array}{l}\text { a. Diploma from prestige } \\
\text { university }\end{array}$ & & & & \\
\hline b. Knowledge and skills & & & & \\
\hline c. Friends or connections & & & & \\
\hline 5. Your friend paid the bribe & $\begin{array}{l}\text { Least } \\
\text { often }\end{array}$ & Less often & $\begin{array}{l}\text { More } \\
\text { often }\end{array}$ & $\begin{array}{l}\text { Most } \\
\text { often }\end{array}$ \\
\hline a. He didn't study well & & & & \\
\hline b. He pays all the time & & & & \\
\hline c. Teacher demanded money & & & & \\
\hline d. All system is corrupted & & & & \\
\hline $\begin{array}{l}\text { 6. The biggest problem in education } \\
\text { is: }\end{array}$ & $\begin{array}{c}\text { Least } \\
\text { Important }\end{array}$ & $\begin{array}{c}\text { Less } \\
\text { Important }\end{array}$ & $\begin{array}{c}\text { More } \\
\text { Important }\end{array}$ & $\begin{array}{c}\text { Very } \\
\text { Important }\end{array}$ \\
\hline $\begin{array}{l}\text { a. Bad opportunities after } \\
\text { graduation }\end{array}$ & & & & \\
\hline b. Bad learning, small quality & & & & \\
\hline c. Corruption & & & & \\
\hline d. Lack of equipment, books & & & & \\
\hline $\begin{array}{l}\text { 7. When I can pass only } 1 \text { exam, the } \\
\text { most suitable situation for me is: }\end{array}$ & Pass 1,2 fa & $\begin{array}{r}\text { Pass } 1 \\
\text { bu }\end{array}$ & $\begin{array}{l}\text { fail } 1, \\
1\end{array}$ & ss 1 , buy 2 \\
\hline 8. Bribery in education for me is: & $\begin{array}{l}\text { Strongly } \\
\text { disagree }\end{array}$ & Disagree & Agree & $\begin{array}{l}\text { Strongly } \\
\text { agree }\end{array}$ \\
\hline
\end{tabular}




\begin{tabular}{|c|c|c|c|c|}
\hline b. Normal practice & & & & \\
\hline $\begin{array}{c}\text { c. Possible solution } \\
\text { people }\end{array}$ & & & & \\
\hline e. "Thank you form" & & & & \\
\hline f. Salary for teacher & & & & \\
\hline $\begin{array}{l}\text { 9. Corruption in the education } \\
\text { system still exists because of: }\end{array}$ & $\begin{array}{l}\text { Strongly } \\
\text { disagree }\end{array}$ & Disagree & Agree & $\begin{array}{c}\text { Strongly } \\
\text { agree }\end{array}$ \\
\hline a. Laziness of the students & & & & \\
\hline b. Demoralization of the society & & & & \\
\hline $\begin{array}{l}\text { c. System creates such an oppor- } \\
\text { tunity, where you can easily pay }\end{array}$ & & & & \\
\hline $\begin{array}{l}\text { d. Only diploma as a document } \\
\text { is important }\end{array}$ & & & & \\
\hline General information & BA & MA & Other: & \\
\hline Age & Male & Female & & \\
\hline Level of studying & No & & \\
\hline Sex & & & & \\
\hline $\begin{array}{l}\text { Have you meet personally with } \\
\text { corruption at universities? }\end{array}$ & Yes & & \\
\hline I'm affiliated with university: & & & \\
\hline
\end{tabular}

Appendix B. Statistics data.

\begin{tabular}{|c|c|c|c|c|}
\hline $\begin{array}{l}\text { 1. Situations in which corruption } \\
\text { occurs most often (in your } \\
\text { previous university): }\end{array}$ & $\begin{array}{l}\text { Least } \\
\text { often }\end{array}$ & Less often & $\begin{array}{l}\text { More } \\
\text { often }\end{array}$ & $\begin{array}{l}\text { Most } \\
\text { often }\end{array}$ \\
\hline $\begin{array}{l}\text { a. While entering university } \\
\text { process }\end{array}$ & $\begin{array}{c}58,1 \% \\
(18)\end{array}$ & $29,0 \%(9)$ & $16,1 \%(5)$ & $0,0 \%(0)$ \\
\hline b. For passing exams/test & $16,1 \%(5)$ & $16,1 \%(5)$ & $\begin{array}{c}41,9 \% \\
(13)\end{array}$ & $25,8 \%(8)$ \\
\hline $\begin{array}{l}\text { c. For graduation process (final } \\
\text { exam, MA paper etc) }\end{array}$ & $9,7 \%(3)$ & $19,4 \%(6)$ & $\begin{array}{c}45,2 \% \\
(14)\end{array}$ & $25,8 \%(8)$ \\
\hline $\begin{array}{l}\text { d. Other: to obtain scholarship, } \\
\text { dormitory, documents, } \\
\text { library. }\end{array}$ & $\begin{array}{l}51,6 \% \\
(16)\end{array}$ & $\begin{array}{c}41,9 \% \\
(13)\end{array}$ & $6,5 \%(2)$ & $0,0 \%(0)$ \\
\hline \multirow[t]{2}{*}{$\begin{array}{l}\text { 2. What is the quality of studying. } \\
\text { Underline } 1 \text { option }\end{array}$} & Very bad & Poor & Good & $\begin{array}{l}\text { Very } \\
\text { good }\end{array}$ \\
\hline & $3,1 \%(1)$ & $\begin{array}{c}\mathbf{5 3 , 1 \%} \\
(\mathbf{1 7})\end{array}$ & $\begin{array}{c}37,5 \% \\
(12)\end{array}$ & $6,3 \%(2)$ \\
\hline $\begin{array}{l}\text { 3. At the university important for } \\
\text { you is (evaluate each option): }\end{array}$ & $\begin{array}{c}\text { Least } \\
\text { Important }\end{array}$ & $\begin{array}{c}\text { Less } \\
\text { Important }\end{array}$ & $\begin{array}{c}\text { More } \\
\text { Important }\end{array}$ & $\begin{array}{c}\text { Very } \\
\text { Important }\end{array}$ \\
\hline a. Finding new friends & $6,5 \%(2)$ & $22,6 \%(7)$ & $\begin{array}{c}58,1 \% \\
(18)\end{array}$ & $12,9 \%(4)$ \\
\hline b. Establishing new connections & $0,0 \%(0)$ & $25,8 \%(8)$ & $\begin{array}{c}61,3 \% \\
(19)\end{array}$ & $12,9 \%(4)$ \\
\hline
\end{tabular}




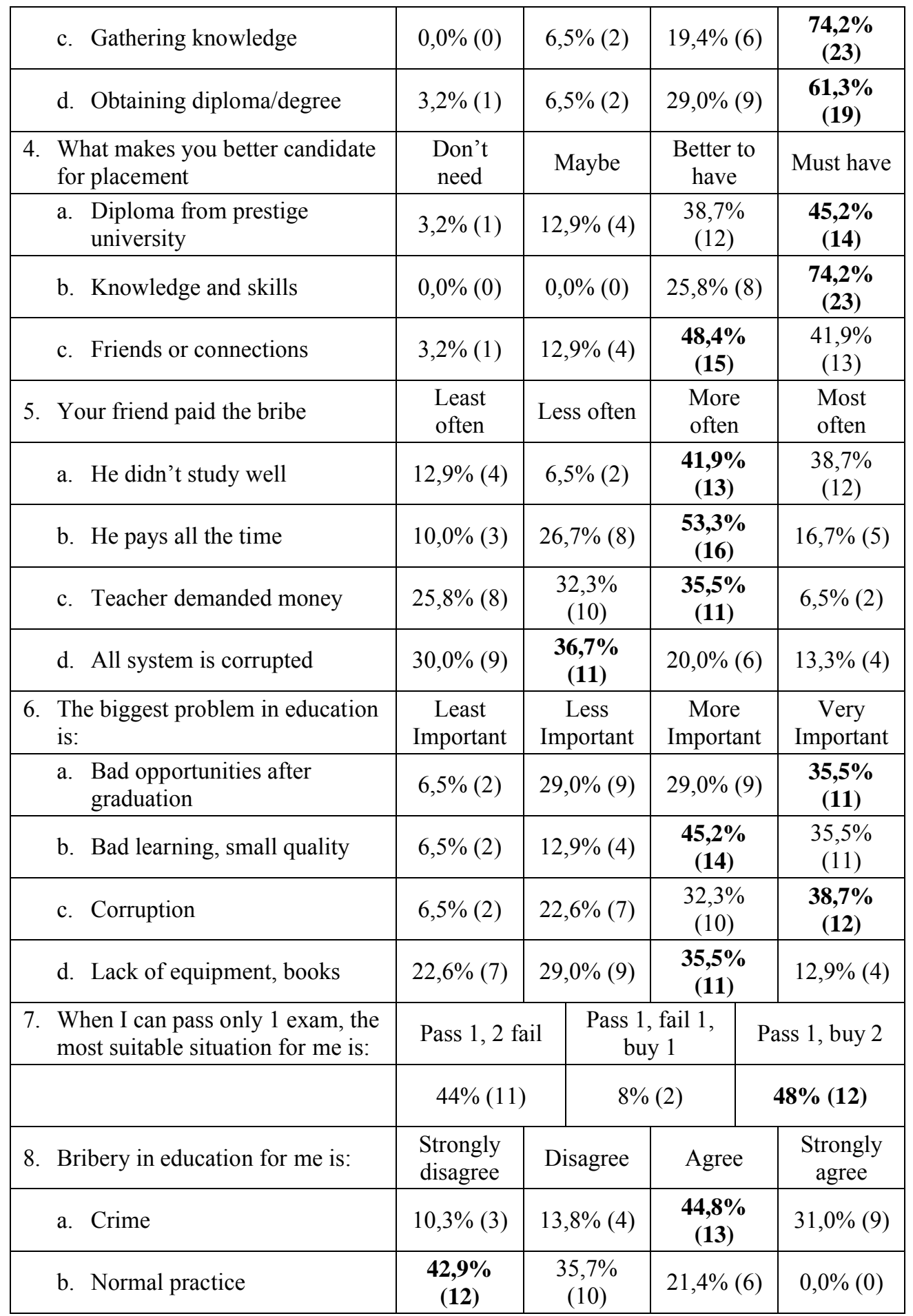


Students are the major source for proliferation of corruption in higher education...

\begin{tabular}{|c|c|c|c|c|}
\hline c. Possible solution & $32,1 \%(9)$ & $\begin{array}{c}35,7 \% \\
(10)\end{array}$ & $25,0 \%(7)$ & $7,1 \%(2)$ \\
\hline $\begin{array}{l}\text { d. Production bad-educated } \\
\text { people }\end{array}$ & $0,0 \%(0)$ & $7,1 \%(2)$ & $\begin{array}{c}50,0 \% \\
(14)\end{array}$ & $\begin{array}{c}42,9 \% \\
(12)\end{array}$ \\
\hline e. "Thank you form" & $34,6 \%(9)$ & $34,6 \%(9)$ & $30,8 \%(8)$ & $0,0 \%(0)$ \\
\hline f. Salary for teacher & $\begin{array}{l}34,5 \% \\
(10)\end{array}$ & $24,1 \%(7)$ & $27,6 \%(8)$ & $13,8 \%(4)$ \\
\hline $\begin{array}{l}\text { 9. Corruption in the education } \\
\text { system still exists because of: }\end{array}$ & $\begin{array}{l}\text { Strongly } \\
\text { disagree }\end{array}$ & Disagree & Agree & $\begin{array}{l}\text { Strongly } \\
\text { agree }\end{array}$ \\
\hline a. Laziness of the students & $6,7 \%(2)$ & $3,3 \%(1)$ & $\begin{array}{c}70,0 \% \\
(21)\end{array}$ & $20,0 \%(6)$ \\
\hline b. Demoralization of the society & $6,7 \%(2)$ & $13,3 \%(4)$ & $\begin{array}{c}63,3 \% \\
(19)\end{array}$ & $20,0 \%(6)$ \\
\hline $\begin{array}{l}\text { c. System creates such an } \\
\text { opportunity, where you can } \\
\text { easily pay }\end{array}$ & $6,7 \%(2)$ & $16,7 \%(5)$ & $\begin{array}{c}46,7 \% \\
(14)\end{array}$ & $30,0 \%(9)$ \\
\hline $\begin{array}{l}\text { d. Only diploma as a document } \\
\text { is important }\end{array}$ & $10,0 \%(3)$ & $23,3 \%(7)$ & $\begin{array}{c}56,7 \% \\
(17)\end{array}$ & $10,0 \%(3)$ \\
\hline \multicolumn{5}{|c|}{ General information } \\
\hline \multirow[t]{2}{*}{ Age } & $16-$ & $17-19$ & $20-22$ & $23+$ \\
\hline & $3,6 \%(1)$ & $25 \%(7)$ & $\begin{array}{c}39,3 \% \\
(11)\end{array}$ & $32,1 \%(9)$ \\
\hline \multirow[t]{2}{*}{ Level of studying } & BA & MA & Other: & \\
\hline & $50 \%(14)$ & $50 \%(14)$ & & \\
\hline \multirow[t]{2}{*}{ Sex } & Male & Female & & \\
\hline & $\begin{array}{c}53,6 \% \\
(15)\end{array}$ & $\begin{array}{c}46,4 \% \\
(13)\end{array}$ & & \\
\hline \multirow[t]{2}{*}{$\begin{array}{l}\text { Have you meet personally with } \\
\text { corruption at universities? }\end{array}$} & Yes & No & & \\
\hline & $\begin{array}{c}35,7 \% \\
(10)\end{array}$ & $\begin{array}{c}64,3 \% \\
(18)\end{array}$ & & \\
\hline
\end{tabular}

\section{References and Notes:}

1. „Anti-corruption issues in education”, International Institute for Educational Planning, http://www.iiep.unesco.org/fileadmin/user_upload/Research_Highlights_Corruption/p df/Rapport_Azerbaijan_AZ.pdf

2. Daniel Heradstveit, Matthew G. Bonham, ,The Psychology of Corruption in Azerbaijan and Iran" in Oil in the Gulf, Ashgate, Chippenham 2004, 72-99.

3. Hamlet Isakhanli, "Strengths and Weaknesses of Private Universities in a Transition Economy: A View From 
Azerbaijan",http://portal.edu.az/English/Pages/strengthsandweaknessesofprivateunive $\underline{\text { rsities.aspx }}$

4. Hamlet Isakhanli, "On Education System In Transition Economy: A View From Azerbaijan”, Baku: Khazar University Press 2006, p. 41, http://dspace.khazar.org/jspui/bitstream/123456789/1001/1/on\%20education\%20syste m_Isaxanli.pdf

5. Heyneman P. Stephen., „Education and Corruption”, International Journal of Educational Development, vol. 24, No. 6 (November 2004): 637-648, http://www.vanderbilt.edu/peabody/heyneman/PUBLICATIONS/Education $\% 20 \& \% 2$ 0Corruption.pdf

6. IvetaSilova, Mark S. Johnson and Stephen P. Heyneman, "Education and the Crisis of Social Cohesion in Azerbaijan and Central Asia", Comparative Education Review, vol. 51, no. 2 (February 2007):159-180,

http://www.vanderbilt.edu/peabody/heyneman/PUBLICATIONS/Ed.\%20and\%20the $\% 20$ Crisis $\% 20$ of $\% 20$ Social $\% 20$ Cohesion $\% 20$ in $\% 20$ Azerbaijan $\% 20$ and $\% 20$ Central $\%$ 20Asia.pdf

7. IvetaSilova, VirginijaBudiene, Mark Bray, "Education in a Hidden Marketplace: Monitoring of Private Tutoring", Open Society Institute 2006, http://www.soros.org/initiatives/esp/articles_publications/publications/hidden 200702 16/hidden 20070216.pdf

8. Jacques Hallack, Muriel Poisson, „Ethics and Corruption in education”, Policy Forum, no. 15, Paris 2002, http://www.unesco.org/iiep/PDF/Forum15.pdf

9. Paul Temple, GeorgyPetrov, "Corruption in Higher Education: Some Findings from the States of the Former Soviet Union", Higher Education Management and Policy, vol. 16, no. 1, 2004, p. 89-97, http://www.oecd.org/dataoecd/22/33/37443688.pdf

10. Randall Collins, "Comparative and Historical Patterns of Education" in Handbook of the Sociology of Education, ed. Maureen T. Hallinan(New York: Kluwer Academic/Plenum Publishers, 2000), p. 213-239.

11. Riaño J., Heinrich F., Hodess R., Global Corruption Barometer 2010, Transparency International, (December 2010).

12. RuzannaRashidgizi, "Everybodygets a piece", Chalkboard, 25 November 2009, http://chalkboard.tol.org/azerbaijan2(accessed December 17, 2011).

13. Shahin Abbasov, "Fighting Corruption in Azerbaijan: A Mission with Teeth?”,Eurasianet, 23 February 2011,http://www.eurasianet.org/node/62947 (accessed December 17, 2011).

14. The 2009 Corruption Perceptions Index, http://www.transparency.org/content/download/53383/851857/CPI+2009_Sources_by country.pdf

15. The 2010 Corruption Perceptions Index, http://www.transparency.org/content/download/55725/890310

16. Психологический Центр, “Коррупция в системе образования: состояние, причины и пути решения (социологический и социально-психологический анализ)". http://psychology.az/project_corr.php (accessedDecember 17, 2011). 


\title{
Summary
}

\section{Students are the major source for proliferation of corruption in higher education in Azerbaijan.}

\author{
Volodymyr V. Gulyk \\ Azerbaijan Diplomatic Academy, \\ Baku, Azerbaijan
}

The soviet era brought various diseases to fifteen different countries, but corruption is one of the most dangerous. The aim of the studies described here was to explore student's opinion and their behavior as a main reason of proliferation of corruption. The author of the article conducted interviews and broadcasted the questionnaire among the students within different background. The results proved that there is significant amount of students, who regularly pay bribes, because they do not study well, or at all.

Key words: Corruption, education, Azerbaijan, bribe, soviet mentality, students, case study, questionnaire, Baku universities. 